\title{
Women Empowerment: Analysis of the Role of Self Help Groups in Empowering Rural Women in Goa
}

\author{
Elizabeth Joey Henriques*
}

\begin{abstract}
Self Help Groups have emerged as an important mechanism to bring about socioeconomic change in society. Various studies indicate the positive impact that SHGs have had on employment generation, savings, incomes, poverty alleviation and women empowerment. The present study, based on primary data sourced from women members of SHGs located in the state of Goa is an attempt to understand the impact of group membership on its members, particularly women. An attempt has also been made to throw light on the pivotal role that the Self Help Group Promoting Agencies essay in realising the goal of women empowerment. The study also analyses the independence that women exhibit in taking decisions, be it in the economic or political domain.
\end{abstract}

Key words: Self Help Groups, Women, Empowerment, Promoting Agencies.

\subsection{Introduction}

In recent years, the goal of women empowerment has become central to many a state or non-state programme and policy. The United Nations Millennium Declaration has also emphasised the need to promote gender equality and empowerment of women. Self Help Groups (SHGs) have come to be looked upon as important mechanisms that can facilitate the achievement of this objective. Studies indicate how SHGs have essayed an important role in improving the life of the SHG members, women in particular and empowering them economically, socially and politically. Musokotwane et. al. (2001) defined empowerment as a process through which women and men in disadvantaged positions increase their access to knowledge, resources, decision-making powers and raise their awareness of participation in their communities in order to have control over their own environment.

*Associate Professor of Economics, Government College of Commerce, Borda, Margao, Goa. (email: lizbet@ rediffmail.com) 
Kabeer (2005) identifies resources, agency and achievements as the driving forces of women empowerment, defining women empowerment as a process whereby those who have been denied the ability to make strategic life changes, acquire the ability to do so. Goetz and Gupta's (1994) studies on women's control of credit in Bangladesh indicate that most women borrowers have only partial control over loans, or have relinquished all control to male members of the family. Depending on the individual study, it would appear that about $20 \%-50 \%$ of Bangladeshi women hand over the entire loan to males in the family. Zaman (2001) asserts in his impact study of micro credit in Bangladesh (a case study of BRAC) that Self Help Groups intermediated by micro credit have positive effects on women. They have played a valuable role in reducing the vulnerability of the poor through asset creation, income and consumption smoothing, provision of emergency assistance and empowering and emboldening women by giving them control over assets and increased self-esteem and knowledge.

Gamoorthy's (2001) study noted an improvement in levels of women empowerment sue to SHGs. Women had become more assertive and participated in household decision making. Moreover due to the SHG movement, women had also become financially independent. Sundaraj (2012) in his study concluded that there is a positive correlation between the level of entrepreneurial development of women and their economic and social empowerment. Political empowerment however is still at the grassroot level. The present paper is an attempt to study the impact of SHG membership on the women respondents.

\subsection{Objectives}

The main objectives of the study are:

a) To detail the socio-economic profile of the respondents and SHGs.

b) To understand the role played by the SHG Promoting Agencies in empowering the women respondents.

c) To study the impact of SHGs on the employment status of the respondents.

d) To throw light on the overall impact that SHG membership has had on the empowerment of the respondents.

\subsection{Methodology}

For the purpose of this paper, both primary and secondary data has been employed. A total of 300 respondents, exclusively women, were selected as the sample from a total of 40 SHGs. The selected SHGs are those that have been formed by the District Rural Development Agencies under the SGSY in Goa. The SHGs are located in 
different 'talukas' of the two districts of the state of Goa. A structured questionnaire was administered to the respondents. The responses of the respondents to the questions set as also discussions held with them have been taken into account to arrive at the findings of the research paper. Furthermore, discussions were also held with the officials of the Self Help Group Promoting Institutions to get further insights on how the SHGs have made a difference in the lives of these women respondents. The paper also relies on secondary data sourced from research papers on the subject, books as also on online material available on the subject.

\subsection{Research questions}

The paper seeks to explore the answers to the following research questions which have implications for the empowerment of women in general.

- What changes in their personality traits have these women respondents witnessed in themselves post the membership of the SHGs?

- What role has the SHGPI's essayed in enabling these women to become more empowered?

- Did the interactions with other members have any impact on the political empowerment of these women?

- What is their contribution to the household in terms of expenditure sharing? Do they have a voice in the decision-making at home? What is the pattern of loan usage? Has the membership of the SHG motivated the members to take up some income generating activity and be economically independent?

- Have they made any contribution in their neighbourhood and to the society at large?

\subsection{Limitations of the study}

The study is limited by the number of respondents selected as the sample. The sample consists of 300 respondents. Selection of a larger sample could possibly have generated more conclusive findings. Furthermore, not all aspects of empowerment have been taken into consideration in the findings of this paper. The researcher has restricted the scope of the paper to probing answers to the research questions posed.

\subsection{Research Findings}

\subsection{Socio-economic profile of respondents}

Table 1 shows the socio-economic profile of respondents. It can be seen from Table 1 that a majority of the women members of the SHGs are young. A significant 
percentage of the members belong to the age group 35-44 years. Just one percent of the sample i.e a total of three respondents were 65 years and above.

Table 1: Socio-Economic Profile of Women Respondents

\begin{tabular}{|c|c|c|c|}
\hline S. No. & Variables & Frequencies & Percentage \\
\hline \multirow[t]{7}{*}{1.} & Classification by Age & & \\
\hline & 15 Years to 24 Years & 9 & 3.0 \\
\hline & 25 Years to 34 Years & 71 & 23.7 \\
\hline & 35 Years to 44 Years & 116 & 38.7 \\
\hline & 45 Years to 54 Years & 70 & 23.3 \\
\hline & 55 Years to 64 Years & 31 & 10.3 \\
\hline & 65 Years and above & 3 & 1.0 \\
\hline & Total & 300 & 100 \\
\hline \multirow[t]{6}{*}{2.} & Classification by Caste & & \\
\hline & Scheduled Castes & 2 & 0.7 \\
\hline & Scheduled Tribes & 53 & 17.7 \\
\hline & Other Backward Classes & 118 & 39.3 \\
\hline & General Category & 127 & 42.3 \\
\hline & Total & 300 & 100 \\
\hline \multirow[t]{5}{*}{3.} & Classification by Religion & & \\
\hline & Hindus & 281 & 93.7 \\
\hline & Catholics & 18 & 6.0 \\
\hline & Muslims & 1 & 0.3 \\
\hline & Total & 300 & 100 \\
\hline \multirow[t]{4}{*}{4.} & Classification by Family Type & & \\
\hline & Joint Family & 66 & 22.0 \\
\hline & Nuclear Family & 234 & 78.0 \\
\hline & Total & 300 & 100 \\
\hline \multirow[t]{5}{*}{5.} & Classification by way of Marital Status & & \\
\hline & Married & 246 & 82.0 \\
\hline & Unmarried & 20 & 6.7 \\
\hline & Widow & 34 & 11.3 \\
\hline & Total & 300 & 100 \\
\hline \multirow[t]{4}{*}{6.} & Educational Status & & \\
\hline & Literate & 223 & 74.3 \\
\hline & Illiterate & 77 & 25.7 \\
\hline & Total & 300 & 100 \\
\hline
\end{tabular}




\begin{tabular}{|c|l|c|c|}
\hline 7. & $\begin{array}{l}\text { Classification by way of Type of } \\
\text { Accomodation }\end{array}$ & & \\
\hline & Owned Accomodation & 293 & 97.7 \\
\hline & Rented Accomodation & 7 & 2.3 \\
\hline & Total & $\mathbf{3 0 0}$ & $\mathbf{1 0 0}$ \\
\hline 8. & Size of Household & 75 & 21.9 \\
\hline & Less than 4 & 215 & \\
\hline & Between 4 and 7 & 10 & 3.4 \\
\hline & More than 7 & $\mathbf{3 0 0}$ & $\mathbf{1 0 0}$ \\
\hline & Total & 286 & 95.3 \\
\hline 9. & Type of SHG & 14 & 4.7 \\
\hline & Exclusively women SHGs & $\mathbf{3 0 0}$ & $\mathbf{1 0 0}$ \\
\hline & Mixed Membership & & \\
\hline & Total & 98 & 32.7 \\
\hline 10. & Promoting Agency & 46 & 15.3 \\
\hline & Government & 156 & 52.0 \\
\hline & Bank & $\mathbf{3 0 0}$ & $\mathbf{1 0 0}$ \\
\hline & NGO & & \\
\hline & Total & & \\
\hline
\end{tabular}

Source: Field data

Scheduled Castes and Scheduled Tribe respondents comprised just $18.4 \%$ of the sample while a vast majority was made up of members belonging to the $\mathrm{OBC}$ and general category. The sample comprised of women predominantly from the Hindu community with Muslims and Catholics making up just $6.3 \%$ of the sample. The high cost of living manifests itself in the preference for nuclear families. A significantly large percentage of the respondents were married and had owned accommodation. Just seven of the respondents lived in tenanted houses. The household size ranged from a minimum of two to a maximum of nine members. A majority of the respondents were members of SHGs that were exclusively formed with women members while less than five percent of the sample selected belonged to groups having mixed membership. The government, banks and NGOs were instrumental in the promotion of these groups. Less than quarter of the sample selected comprised of women who had no schooling whatsoever. While six and two members respectively were graduates and postgraduates, the rest of the women had educational qualifications varying from primary education to Higher Secondary Education. Most of the members were Konkani speaking while some were conversant with the English language too. 


\subsection{Impact of NGO/SHGPI on the community}

Both the state and non-state players have been instrumental in the formation of SHGs in the state of Goa. The former sets up SHGs through a number of its departments but more particularly through the District Rural Development Agencies. These groups comprise of members of the below poverty line section of the Goan society. Banks, NGO's, farmers clubs, social workers have also played a vital role in galvanizing people into groups. The impact that these Self Help Group Promoting Agencies (SHGPIs) had in the lives of the members more specifically the women is noteworthy. The SHGPIs have played a vital role in encouraging SHG members to save and to access credit. The NGOs are also responsible for granting the SHG members an opportunity to become economically independent by establishing micro-level entreprises. They have increased the mobility of the members. They are responsible for generating a sense of awareness among the members' vis-à-vis local issues. For example, members today make representations to authorities and participate in rallies and agitations with respect to garbage disposal, pollution and other social issues. They have developed skill competency among group members through training programmes. They have instilled in the members a sense of financial discipline, inculcating in them a banking culture of availing and repaying loans both from the thrift fund as also bank credit. They have enabled the women members in particular to become participants in the household decision-making. They have forged bonds of unity, kinship and a strong sense of togetherness among the group members. The NGOs have succeeded in providing the members a platform to showcase their skills and talents by organizing various competitions. NGOs associated with the Watershed Development Projects have exposed the villagers to new technology. The role of the NGO is not merely restricted to financial intermediation but they have invested in human and social capital at the grassroot level.

\subsection{Impact on employment and income generation}

One of the key reasons that women become members of SHGs is the easy access they have to credit. These SHGs disburse loans either from the thrift fund they maintain or through credit linkage with the banks not just for consumption smoothening but also for setting up some micro enterprise or to enable the woman member to be self employed. Not all the SHGs that form a part of the sample however have taken to productive income generating activities as a group. A majority of the groups lend to members to start some activity or to expand an existing one. Table 2 indicates the impact that the SHG membership had on the employment and income profile of the women members. The data in Table 2 suggests that the SHG membership has been an enabling 
22 | MANTHAN: Journal of Commerce and Management, Volume 3, Issue 2

factor as far as employment generation is concerned. Post-SHG membership, there has been a positive impact on the number of women employed.

Table 2: Pre and Post SHG Membership Employment Profile of the Respondents

\begin{tabular}{|l|c|c|}
\hline Employment Status & Pre-SHG Membership & Post-SHG Membership \\
\hline Unemployed & $181(60.3 \%)$ & $67(23.3 \%)$ \\
\hline Employed & $119(39.7 \%)$ & $233(77.7 \%)$ \\
\hline Total & $\mathbf{3 0 0}(\mathbf{1 0 0 \%})$ & $\mathbf{3 0 0}(\mathbf{1 0 0 \%})$ \\
\hline
\end{tabular}

Source: Compiled from field data

Figure 1 details the type of activities these Respondents are engaged in. The women are now in a position to contribute to the family income bowl. Interactions with them indicated that post SHG membership, they don't have to seek money from their spouses to meet their personal expenditures.

\section{Employment Status After Joining SHG}

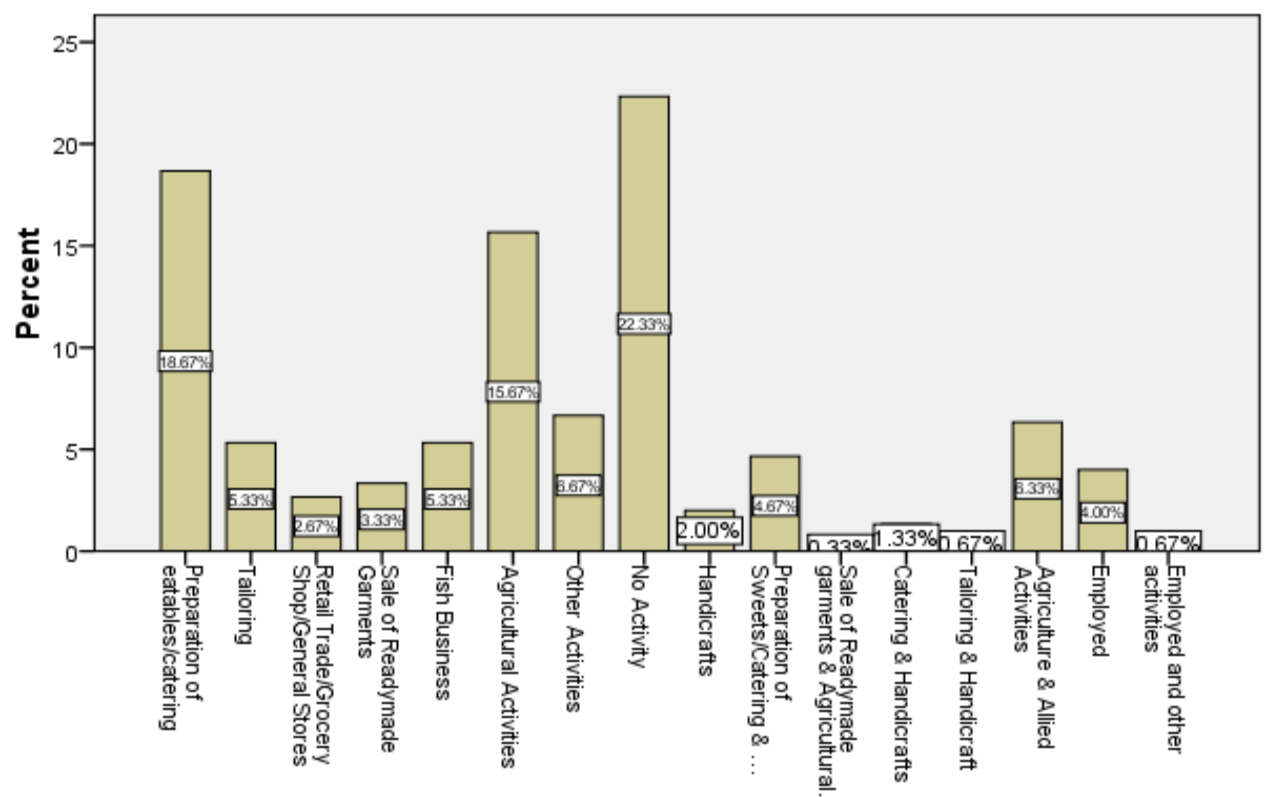

Figure 1: Employment Status after Joining SHG 
They not only financed their personal needs themselves but from time to time bought gifts for their family members and also purchased assets for the house. They were economically independent and revelled in the experience of being so.

\subsection{Loan usage by women members of SHG}

An analysis of the loan activities of the respondents indicates that the members have borrowed for both productive and unproductive purposes. A total of 44 respondents have not availed of credit from the SHGs, either from the thrift fund or by way of bank loan. While a majority of the members have utilised the loan availed of for non-income generating activities, a total of 82 respondents $(27.3 \%)$ have borrowed funds to facilitate the setting up or strengthening of a new or existing business activity. The decision to avail a loan from the SHG however, in most cases is a decision taken by the household at large in particular after consultation with the spouse and in very rare a case is it an independent decision of the respondent. It can be inferred therefore that not many of the women exercise their independence in the decision making process related to availing of credit and its usage.

Table 3: Loan Usage by Respondents

\begin{tabular}{|l|c|c|c|}
\hline & Frequency & Percent & Cumulative Percent \\
\hline Income Generating Activity & 82 & 27.3 & 32.0 \\
\hline Non-Income Generating Activity & 116 & 38.7 & 77.3 \\
\hline Both & 58 & 19.3 & 100.0 \\
\hline Total & 256 & 85.3 & - \\
\hline Loan Not Availed & 44 & 14.7 & - \\
\hline Total & $\mathbf{3 0 0}$ & $\mathbf{1 0 0 . 0}$ & - \\
\hline
\end{tabular}

Source: Field data

\subsection{Political empowerment}

An important construct to gauge women empowerment is their awareness of political issues and their decision making authority at the time of exercising their franchise. Interactions with the women respondents revealed that while none of them were actively involved in politics or interested in contesting elections, their awareness of political issues was not debatable. The respondents revealed that at their regular SHG meetings, political issues were also animatedly discussed. The connect between the respondents and the political class has actually strengthened post their SHG membership. The respondents have benefitted from the politicians as the latter provide them and their 
groups with donations, sponsor picnics, pilgrimages, provide them with skill based training and even goodies just prior to any festival. However, the women opined that at the time of elections, their vote is not conditioned by the largesse that they obtain from the political leaders but by decisions that are either independently arrived at or after consultation with their family members, in particular, their spouses. This indicates that when it comes to exercising their voting right, the decision making process is not necessarily one made by the woman herself. Thus, while the women are more amenable to discussing and debating politics post SHG membership, their decision making power vis-à-vis 'whom to vote for' is severely compromised.

\subsection{Women empowerment: Field experiences}

Interactions with the respondents revealed how SHGs had enabled the women to improve the quality of their lives. Some respondents reported the happiness they felt when they made their first independent purchases with their own earnings or the pleasure in purchasing gifts for their family members. There were others for whom, earlier, mobility, willingly or unwillingly, was confined to the four walls of their homes. This is a phenomenon of the past. The SHGs have changed the lives of these women in large measure. Social interactions have increased. Their immediate family is no longer their only support system. In times of need and misfortune, they find solace in their extended family - the SHG itself. The regular monthly meetings serve as stress busters and provide an opportunity to the members to share ideas and opinions and even discuss their personal problems. There have been instances reported where the group as a whole has played an instrumental role in solving personal conflicts arising in members' homes. SHG members offer 'Shramadan', participate in community development programmes and even make monetary contributions to local temples. While some respondents take pride in the micro-enterprises they have established and the additional jobs they have helped generate, others opine how the regular interactions with other SHG members have made their lives more vibrant. The members feel more confident and courageous enough to take on the authorities and also address social evils. They have become more 'informed' and therefore more 'empowered' citizens.

\subsection{Conclusion}

From the study, it can be concluded that the Self Help Group Promoting Agencies have acted as catalysts in the process of empowering women. The SHGs have improved the social network for these women, provided them with employment, and enabled them to become economically independent. Through the group activity they 
have also contributed to the creation of social assets. The SHG membership has made these women more confident of themselves and of their abilities. However, despite being economically independent, not all of the women respondents enjoyed the power of decision making. Decisions related to availing credit, usage of credit or for that matter exercising her franchise were decisions largely dependent on the spouse or conditioned by other factors and not decisions of her own. Despite this lacunae however, it can be stated that there is no denying the fact that Self Help Groups have played an instrumental role in empowering women.

\section{References}

Field, A. (2005). Discovering Statistics using SPSS (2 ${ }^{\text {nd }}$ Edition), Sage Publications.

Gamoorthy, A.Vinaya. (2001). Women Empowerment through SHGs: A Case Study in North Tamil Nadu. Study commissioned by SEWA, SEWA Publications.

Goetz, Anne Marie \& Gupta, Rina Sen. (1996). Who takes credit? Gender, power, and control over loan use in rural credit programmes in Bangladesh. World Development. 24(1): 45-63.

Jerinabi U. (2008). Micro Enterprises for Women- Competitiveness, Challenges and Prospects for New Global Environment. Discovery Publishing House Pvt. Ltd: New Delhi.

Kabeer, Naila. (2005). Is microfinance a 'magic bullet' for women's empowerment? Analysis of Findings from South Asia. Economic and Political Weekly, 40(44/45): 47094718 .

Kabeer, Naila. (2002). Resources, Agency, Achievements: Reflection on the Measurement of Women's Empowerment. In B Sevefjord and B Olsson (eds), Discussing Women's Empowerment-Theory and Practice, Swedish International Development Agency: Sweden.

Musokotwane, Regina, Siwale, Rev Michael, \& Nkhata, Bentry (2001). Gender Awareness and Sensitization in Basic Education. Paris: Peoples Action Forum, UNESCO, Basic Education Division. 
26 | MANTHAN: Journal of Commerce and Management, Volume 3, Issue 2

Perumal, V.M.S. (2005). SHGs: Empowering Women at the Grassroots. Social Welfare, 52(4): 5-9.

Sundaraj, J. (2012). Micro finance; A tool for empowering women entrepreneurs. In Edwin Gnanadhas \& P Jegan,(eds.) Micro Finance and Women Entrepreneurship. pp. 347-358, Vol I, B, Digest Publications: Tamil Nadu.

Zaman H. (2001). Assessing the poverty and vulnerability impact of micro credit in Bangladesh: A case study of BRAC. Unpublished background paper for World Bank, World Development Report 2000/2001, Washington. 